\title{
Attenuation and protective efficacy of an O- antigen-deficient mutant of Francisella tularensis LVS
}

Correspondence

Thomas J. Inzana

tinzana@vt.edu
Received 26 January 2007

Revised 2 April 2007

Accepted 3 May 2007

\author{
Jiaxin Li, ${ }^{1} \dagger \ddagger$ Cheryl Ryder, ${ }^{1} \dagger$ Manas Mandal, ${ }^{1} \dagger \S$ Farzana Ahmed, ${ }^{1}$ \\ Parastoo Azadi, ${ }^{2}$ D. Scott Snyder, ${ }^{2}$ Roger D. Pechous, ${ }^{3}$ Thomas Zahrt ${ }^{3}$ \\ and Thomas J. Inzana ${ }^{1}$ \\ ${ }^{1}$ Center for Molecular Medicine and Infectious Diseases, Virginia-Maryland Regional College of \\ Veterinary Medicine, Virginia Polytechnic Institute and State University, Blacksburg, VA, USA \\ ${ }^{2}$ Complex Carbohydrate Research Center, University of Georgia, Athens, GA, USA \\ ${ }^{3}$ Department of Microbiology and Molecular Genetics, Medical College of Wisconsin, Milwaukee, WI, \\ USA
}

Francisella tularensis is a zoonotic, Gram-negative coccobacillus that causes tularemia in humans and animals. F. tularensis subspecies tularensis (type A) and F. tularensis subspecies holarctica (type B) are antigenically similar and more virulent than Francisella novicida in humans. The genetic locus that encodes the LPS $\mathrm{O}$ antigen was found to be substantially different between the type B live vaccine strain (LVS) and F. novicida. One LVS-specific gene with homology to a galactosyl transferase was selected for allelic replacement using a sacB-chloramphenicol expression suicide plasmid, and recombinants were screened for colony morphology on Congo red agar that matched that of $F$. novicida. Two mutants $\left(\mathrm{Wbtl}_{\mathrm{S187Y}}\right.$ and $\left.\mathrm{Wbtl}_{\mathrm{G} 191 \mathrm{~V}}\right)$ were isolated that contained substitutions in conserved motifs in the sugar transamine/perosamine synthetase $(\mathrm{Wbtl})$ of the $\mathrm{O}$-antigen locus, and the latter mutant was extensively tested and characterized. Wbtl $\mathrm{G}_{191 \mathrm{~V}}$ grew at the same rate as the parent strain in Chamberlain's defined medium, completely lacked $\mathrm{O}$ antigen, was serum-sensitive but could grow in a mouse macrophage cell line, had increased resistance to sodium deoxycholate, and was highly attenuated in mice. Complementation of $\mathrm{Wbtl}_{\mathrm{G} 191 \mathrm{~V}}$ with the wild-type wbtl gene in trans restored normal LPS synthesis, phenotypic properties similar to the parent, and virulence in mice. Immunization with $\mathrm{Wbtl}_{\mathrm{G} 191 \mathrm{v}}$ protected mice against a relatively low-dose intraperitoneal challenge with LVS, but was less protective against a high-dose challenge. These results indicate that complete loss of $\mathrm{O}$ antigen alters the surface phenotype and abrogates virulence in $F$. tularensis, but also compromises the induction of full protective immunity against $F$. tularensis infection in mice.

\section{INTRODUCTION}

Francisella tularensis is a Gram-negative, facultative intracellular coccobacillus and the aetiologic agent of tularemia for a wide variety of vertebrate and invertebrate

†These authors contributed equally to this work.

łPresent address: The Institute for Genomic Research, Rockville, MD, USA.

§Present address: College of Pharmacy, University of Southern Nevada, Henderson, NV, USA.

Abbreviations: Amp, ampicillin; $\mathrm{Cm}$, chloramphenicol; ID, intradermal(ly); IN, intranasal(Iy); IP, intraperitoneal(Iy); Kan, kanamycin; LVS, live vaccine strain; PCS, precolostral calf serum; PI, post-inoculation; QuiNAc, Nacetyl quinovosamine; SSH, subtractive suppression hybridization. animal species; tularöemia is a zoonotic disease for humans (Hopla \& Hopla, 1994; Penn, 2005; Sjöstedt, 2005; Timoney et al., 1988; Titball \& Sjöstedt, 2002). F. tularensis can be transmitted to humans by direct contact with infected animals, ingestion of contaminated food or water, bites from infected vectors such as ticks and mosquitoes, and inhalation of infectious aerosols or dust (Hopla \& Hopla, 1994; Penn, 2005; Titball \& Sjostedt, 2002). There are four subspecies of $F$. tularensis: subsp. tularensis (type A), subsp. holarctica (type B), subsp. mediasiatica and subsp. novicida (Sjöstedt, 2005). However, the International Systematics Committee recognizes Francisella novicida as a separate species (http://www.bacterio.cict.fr/ aldl.html). F. tularensis subsp. tularensis is the most virulent subspecies for humans, with an infectious dose 
of as few as 10 cells (Dennis et al., 2001). Patients may present with several clinical forms of tularöemia, the most common being ulceroglandular tularöemia; other forms include oculoglandular, oropharyngeal, intestinal, pneumonic and typhoidal tularöemia. Pneumonic tularöemia has a mortality rate of up to $30 \%$ in the absence of antibiotics (Ellis et al., 2002; Penn, 2005). Based on these factors, F. tularensis has been classified as a category A select agent by the National Institutes of Health and the Centers for Disease Control (Darling et al., 2002; Dennis et al., 2001).

F. tularensis subsp. tularensis is predominately found in North America, and genetically falls into two subtypes: type A East and type A West (Staples et al., 2006). In contrast, subsp. holarctica is more widely distributed and has been isolated in Europe, Asia and North America. Type B strains are associated with morbidity and a somewhat lower mortality rate in humans that type A East strains (Staples et al., 2006). However, F. novicida is considerably less virulent in humans, and is rarely associated with severe disease, although it is highly virulent in mice (Ellis et al., 2002; Hopla \& Hopla, 1994; Titball \& Sjöstedt, 2002).

The factors that are associated with virulence in $F$. tularensis are not well known. Bacterial surface components that contribute to the disease process, or are important for host immunoprotection, have not been clearly identified. Most of the work on F. tularensis surface components has focused on the LPS. The LPS of F. tularensis types A and B is unusual in that the $\mathrm{O}$ antigen consists entirely of dideoxyglycoses, the core oligosaccharide contains mannose in place of heptose (Vinogradov et al., 2002, 1991), and lipid A of the live vaccine strain (LVS) is tetraacylated and lacks phosphate (Vinogradov et al., 2002), while lipid A from a virulent type B isolate also contains a phosphatelinked galactosamine (Phillips et al., 2004). Furthermore, the LPS does not signal through TLR4, is not an agonist for TLR4, and does not induce an inflammatory response (Chen et al., 2005; Cole et al., 2006; Hajjar et al., 2006), which is probably due to the atypical structure of lipid A. However, apart from failing to incite an inflammatory response by the host, the role of the LPS in virulence and immunoprotection is unclear.

The genomes of at least five strains of $F$. tularensis types A and $\mathrm{B}$ and $\mathrm{F}$. novicida have recently been sequenced (available at the National Center for Biotechnology Information), and the genome of type A strain Schu S4 has been annotated (Larsson et al., 2005). However, little information is available regarding genomic differences between the highly virulent $F$. tularensis and the much less virulent $F$. novicida. In order to identify novel genes that may be responsible for virulence in $F$. tularensis, we previously used suppression subtractive hybridization (SSH) with subsp. holarctica LVS as the tester and F. novicida strain U112 as the driver (Ahmed \& Inzana, 2004). Of 76 LVS-specific genes identified, several were found in the wbt $\mathrm{O}$-antigen locus of LVS that were absent in $F$. novicida. One LVS-specific gene, which encoded a galactosyl transferase, was selected for mutagenesis. The mutant was devoid of $\mathrm{O}$ antigen, was more resistant to the bactericidal effects of sodium deoxycholate than its parental strain, was serum susceptible and attenuated in mice, and provided partial protection against an intraperitoneal (IP) high-dose challenge with the parental strain. The significance of $\mathrm{O}$ antigen in $F$. tularensis virulence and induction of host protection is discussed.

This work was presented, in part, at the mid-Atlantic Microbial Pathogenesis meeting (Wintergreen Conference Center, Charlottesville, VA, February 2004).

\section{METHODS}

Bacterial strains and plasmids. The bacterial strains and plasmids used in this work and their sources are listed in Table 1. F. tularensis LVS was obtained as a vaccine vial from Dr May Chu, Centers for Disease Control (April, 2002), was subcultured on chocolate agar, and the cells were suspended in sterile skimmed milk and stored at $-80{ }^{\circ} \mathrm{C}$.

Cultivation of bacteria. Escherichia coli $\mathrm{DH} 5 \alpha$ and Mach1 T1R (Invitrogen) cells were grown at $37{ }^{\circ} \mathrm{C}$ in Luria-Bertani (LB) medium (Difco Laboratories) containing, as appropriate, $100 \mu \mathrm{g}$ ampicillin (Amp) $\mathrm{ml}^{-1}, 10 \mu \mathrm{g}$ chloramphenicol $(\mathrm{Cm}) \mathrm{ml}^{-1}$ or $50 \mu \mathrm{g}$ kanamycin $(\mathrm{Km}) \mathrm{ml}^{-1}$ for selection of recombinant strains. F. tularensis and $F$. novicida strains were grown in Difco Brain Heart Infusion (BHI) broth (Becton Dickinson) supplemented with $0.1 \%$ L-cysteine hydrochloride monohydrate (Sigma) (BHIC) at $37^{\circ} \mathrm{C}$. For culture on agar plates, $5 \%(\mathrm{v} / \mathrm{v})$ sheep blood was added to BHIC agar (BHIBC), and the cultures were incubated at $37{ }^{\circ} \mathrm{C}$ in $5 \% \mathrm{CO}_{2}$, unless otherwise stated. Actinobacillus pleuropneumoniae was grown in supplemented BHI broth or agar, as described previously (Ward et al., 1998).

DNA manipulation. Plasmid isolation, DNA restriction endonuclease digestion, ligation and transformation procedures were carried out using standard protocols (Sambrook et al., 1989). Restriction enzymes and T4 DNA ligase were obtained from New England BioLabs. QIAprep Spin Miniprep and QIAquick gel extraction kits (Qiagen) were used to prepare E. coli plasmid DNA. A PUREGENE DNA isolation kit (Gentra Systems) was used to purify genomic DNA from $F$. tularensis.

Isolation of LVS mutants. Plasmid pPV, containing a $s a c B-\mathrm{Cm}^{\mathrm{R}}$ cassette that confers sucrose sensitivity and resistance to chloramphenicol on Gram-negative cells (Golovliov et al., 2003), was used to mutagenize SSH-identified clone 2-042 (Ahmed \& Inzana, 2004), which was later determined to be $w b t B$ from the O-antigen gene cluster (Prior et al., 2003). A 1500 bp region upstream and a 1500 bp region downstream (Table 1 ) of $w b t B$ were amplified by PCR using primers FA6-7-NF and FA6-7-NR, and FA6-7-CF and FA6-7-CR, respectively. A typical PCR reaction consisted of $1 \times$ PCR HIFI SuperMix (Invitrogen), $0.02 \mu \mathrm{g}$ genomic DNA as template, and $0.4 \mu \mathrm{M}$ of each oligonucleotide primer in $50 \mu \mathrm{l}$ of reaction mixture. The PCR cycling parameters used were $94{ }^{\circ} \mathrm{C}$ for $2 \mathrm{~min}$, followed by 35 cycles of $94{ }^{\circ} \mathrm{C}$ for $30 \mathrm{~s}, 52{ }^{\circ} \mathrm{C}$ for $30 \mathrm{~s}$, and $68{ }^{\circ} \mathrm{C}$ for $2 \mathrm{~min}$, and an additional extension for $5 \mathrm{~min}$ at $68^{\circ} \mathrm{C}$. The $5^{\prime}$ primers included a SalI restriction site and the $3^{\prime}$ primers incorporated either a BamHI restriction site or a PstI restriction site. The upstream and downstream PCR products were digested with SalI/BamHI and SalI/PstI, respectively, and separately cloned into pBluescriptKS + (Stratagene). The two recombinant clones were digested with SalI/ 
Table 1. Bacterial strains, plasmids, and DNA primers used in this study

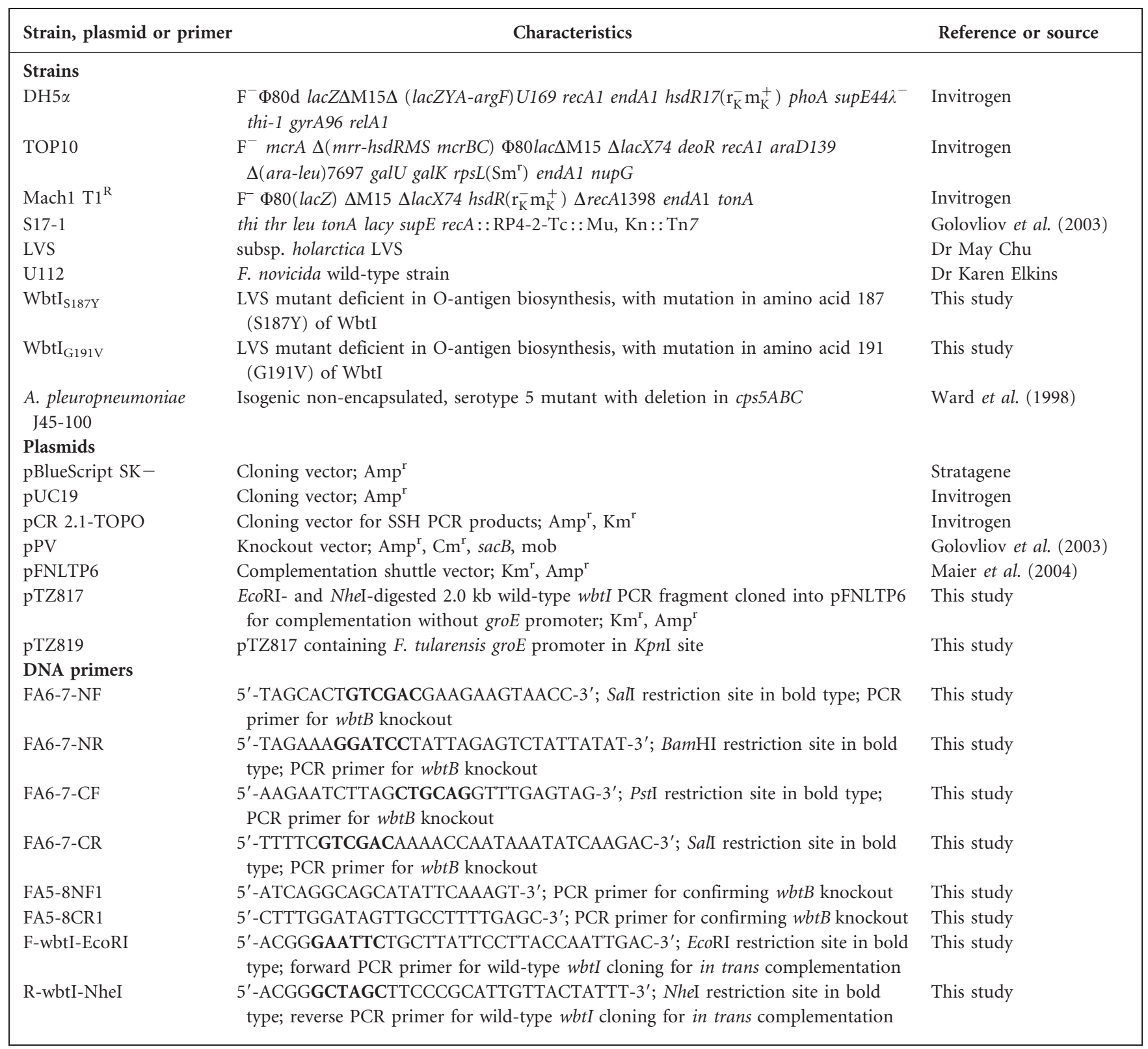

Bam HI and both the upstream and downstream insert fragments were ligated simultaneously into SalI-digested pPV, resulting in plasmid pFA501, which was electroporated into E. coli S17-1. Conjugation of LVS with E. coli S17-1(pFA501) was carried out as described elsewhere (Golovliov et al., 2003). After 4 days of incubation, the colonies were transferred to BHIBC agar containing $100 \mu \mathrm{g}$ polymyxin $\mathrm{B} \mathrm{ml} \mathrm{m}^{-1}$ (to inhibit the donor strain) and $10 \mu \mathrm{g} \mathrm{Cm}$ $\mathrm{ml}^{-1}$. Cm-resistant and polymyxin B-resistant colonies were screened for the presence of the pPV-encoded Amp-resistance gene, which was confirmed by PCR, indicating that pFA501 had integrated into the genome, since the plasmid cannot replicate in the LVS. The Cmresistant colonies were subcultured onto medium containing $5 \%$ sucrose to select for a second recombination event. Sucrose-resistant, $\mathrm{Cm}$-sensitive colonies were isolated to identify clones that had deleted the plasmid from the genome and presumably also the wild-type $w b t B$ gene. Sucrose-resistant colonies were screened for diminished iridescence (indicating a loss of surface carbohydrate) under incandescent light on BHIC agar, followed by further selection of the non-iridescent colonies on BHIC agar containing $75 \mathrm{mg}$ Congo red $1^{-1}$. Screening for dark-red colonies on Congo red agar was used because colonies of $F$. novicida exhibited the dark-red phenotype, whereas colonies of LVS (and type A) were salmon to light pink, indicating surface-component-inhibited binding of Congo red by neutral carbohydrate structures (data not shown). Two colonies that were darker red than the LVS parent were isolated, and PCR (described above) using primers FA5-8NF1 and FA5-8CR1 and Southern blotting were performed to examine the deletion of $w b t B$.

Plasmid construction and wbt/ complementation. A 2.0 kb DNA fragment containing wbtI from the LVS was amplified by PCR using primers F-wbtI-EcoRI and R-wbtI-NheI, as described above. The resulting fragment was cloned into pCR2.1-TOPO, digested with EcoRI and Nhel, gel-purified, and subcloned into the corresponding sites in pFNLTP6 (Maier et al., 2004), resulting in pTZ817. The 
pTZ817 plasmid was then digested with KpnI and ligated with a KpnIdigested fragment carrying the $F$. tularensis groE promoter, resulting in pTZ819, which expressed wbtI from the groE promoter. All insert sequences were confirmed by DNA sequencing. Plasmids pTZ817 and pTZ819 were then electroporated into $F$. tularensis $\mathrm{WbtI}_{\mathrm{G} 191 \mathrm{v}}$. The bacteria were grown to a density of about 110 Klett units (correlating to about $10^{9}$ c.f.u. $\mathrm{ml}^{-1}$ ), washed three times with $0.5 \mathrm{M}$ sucrose, and suspended in $10 \mathrm{ml} 0.5 \mathrm{M}$ sucrose. The plasmid DNA was then electroporated into the bacteria in a $0.1 \mathrm{~cm}$ cuvette using an Electro Cell manipulator ECM630 (BTX), as described previously (Maier et al., 2004). Immediately after electroporation, the cells were suspended into $1 \mathrm{ml}$ of TSB without cysteine and incubated with shaking at $37{ }^{\circ} \mathrm{C}$ for $4 \mathrm{~h}$ before selection on BHIBC agar containing $20 \mu \mathrm{g}$ kanamycin $\mathrm{ml}^{-1}$.

Sequence alignments and computational structural modelling. DNA and protein sequences were aligned with CLUSTAL W (Thompson et al., 1994). The tertiary structures of the wild-type protein WbtI, and mutant proteins $\mathrm{WbtI}_{\mathrm{S} 187 \mathrm{Y}}$ and $\mathrm{WbtI}_{\mathrm{G} 191 \mathrm{~V}}$ were modelled as previously described (Li et al., 2005) to predict the conformational changes caused by residue substitution. Helicobacter pylori aminotransferase Psec (PDB_ID=2FNU, Chain_ID=2FNU_B) with 375 amino acids from the Protein Data Bank (PDB) was used as template for WbtI on the 3D-JIGSAW version 2.0 comparative modelling server (Bates \& Sternberg, 1999) (http://www.bmm.icnet.uk/ 3djigsaw/). The coordinates in PDB formats for 3-D structures of WbtI were constructed and displayed with RasMol version 2.7.3 (Sayle \& Milner-White, 1995).

Extraction of LPS. LPS was purified by aqueous phenol extraction and ultracentrifugation from killed cells, as described by Vinogradov et al. (1995), with modifications. The bacteria were scraped off BHIBC agar into PBS, and following phenol extraction, 4 vols distilled water was added and the mixture dialysed with tap water until no phenol odour remained. Sodium acetate ( $\mathrm{pH}$ 7.0) was added to a final concentration of $30 \mathrm{mM}, 2 \mu \mathrm{g}$ DNase $\mathrm{I} \mathrm{ml}^{-1}$ from bovine pancreas (Sigma-Aldrich) was added and the mixture was incubated for $2 \mathrm{~h}$ at $37^{\circ} \mathrm{C}$, followed by an additional $2 \mathrm{~h}$ incubation with $2 \mu \mathrm{g}$ RNase I ml ${ }^{-1}$ from bovine pancreas (Amersham Pharmacia Biotech). Proteinase K (Sigma-Aldrich) was then added at $20 \mu \mathrm{g} \mathrm{ml}^{-1}$ and the mixture was incubated at $37{ }^{\circ} \mathrm{C}$ for $2 \mathrm{~h}$. Insoluble material was removed by centrifugation at $10000 \mathrm{~g}$ at $4{ }^{\circ} \mathrm{C}$ for $10 \mathrm{~min}$. The LPS was sedimented by ultracentrifugation overnight at $100000 \mathrm{~g}$ at $4{ }^{\circ} \mathrm{C}$, and resuspended in water. The low-speed/high-speed differential centrifugation process was repeated (the low speed was changed to $3000 \mathrm{~g}$ for $15 \mathrm{~min}$ ) until the $A_{260}$ and $A_{280}$ of the supernatant were less than 0.02 , and the LPS was lyophilized.

PAGE and Western blotting. The LPS electrophoretic profile was resolved by SDS-PAGE on Novex 16\% Pre-Cast Tricine Gels (Invitrogen) and Emerald $\mathrm{Q}$ fluorescence staining (Molecular Probes), as described by the manufacturer. Western blotting was carried out using a Trans-Blot SD semi-dry transfer cell (Bio-Rad), and the blots were developed with rabbit polyclonal antiserum to subsp. holarctica LVS (Inzana et al., 2004), rabbit polyclonal antiserum to $F$. novicida U112 ( $1: 1000$ dilution each) or murine $\mathrm{mAb}$ (Chemicon International) to $F$. tularensis $\mathrm{O}$ antigen at $1: 500$ dilution. Anti-rabbit IgG or anti-murine IgG coupled to horseradish peroxidase (HRP; Jackson ImmunoResearch Laboratories) were used as secondary conjugates at $1: 2000$ dilution, and colour was developed with 4-chloro-1-naphthol (Bio-Rad). Rabbit polyclonal antiserum to strain U112 (killed by irradiation) was raised in a New Zealand White rabbit, as previously described (Inzana et al., 2004).

LPS composition and structure. The glycosyl composition of LPS was determined by combined GC/MS of the per-O-trimethylsilyl derivatives of the monosaccharide methyl glycosides, which were produced by acidic methanolysis (Merkle \& Poppe, 1994; York et al., 1985). The samples were then per- $O$-trimethylsilylated by treatment with Tri-Sil (Pierce Chemical) at $80{ }^{\circ} \mathrm{C}$ for $30 \mathrm{~min}$. GC/MS analysis of the per-O-trimethylsilyl methyl glycosides was performed on an HP 5890 GC interfaced to a 5970 MSD, using an All Tech EC-1 fused silica capillary column $(30 \mathrm{~m} \times 0.25 \mathrm{~mm}$ internal diameter $)$.

For structural analysis LPS was hydrolysed $4 \mathrm{~h}$ in $0.1 \mathrm{M}$ sodium acetate, $\mathrm{pH} 4.5$, at $100{ }^{\circ} \mathrm{C}$. Lipid A was extracted using 2.5 vols chloroform: methanol $(2: 1)$, and the remaining aqueous phase was desalted on Dowex 50WX8 and lyophilized. The resultant oligosaccharide core was suspended in dry DMSO. The sample was then permethylated by the method of Ciucanu \& Kerek (1984), suspended in $5 \mathrm{mM}$ EDTA in methanol: water $(1: 1)$, and desalted by adding a few microlitres to a few grains of Dowex 50WX8, previously converted into the ammonium salt. The desalted sample was deposited, along with an equal volume of $20 \mathrm{mM}$ dibasic ammonium citrate, onto a thin layer of matrix, whose components were $200 \mathrm{mg}$ trihydroxyacetophenone $\mathrm{ml}^{-1}$ in methanol, and $15 \mathrm{mg}$ nitrocellulose $\mathrm{ml}^{-1}$ in acetone:2-propanol $(1: 1, \mathrm{v} / \mathrm{v})$, mixed in a $4: 1(\mathrm{v} / \mathrm{v})$ ratio (Sturiale et al., 2005). MALDI-MS analysis was then performed using an Applied Biosystems 4700 mass spectrometer operating in the positive ion mode.

Sensitivity to sodium deoxycholate. The susceptibility of the LVS, mutant strain WbtI $_{\mathrm{G} 191 \mathrm{~V}}$ and complemented strain $\mathrm{WbtI}_{\mathrm{G191V}}:: \mathrm{pFNLTP} / w b t I$ to the bactericidal activity of sodium deoxycholate was evaluated as described elsewhere (Cowley et al., 2000), with modifications. An equal volume of sodium deoxycholate (Sigma) in PBS was added to wells containing $5 \times 10^{5}$ c.f.u. of each strain in $100 \mu$ l to final concentrations (w/v) of $0,0.01,0.1,1$ or $10 \%$. After 45 min incubation at $37^{\circ} \mathrm{C}, 20 \mu \mathrm{l}$ of a $1: 100$ dilution of the mixtures was spread onto BHIBC agar, and bacterial viability was determined after up to 5 days incubation.

Serum bactericidal assay. The bactericidal activity of $0-40 \%$ precolostral calf serum (PCS, which contains no antibodies) for the LVS, mutant $\mathrm{WbtI}_{\mathrm{G} 191 \mathrm{~V}}$ and $\mathrm{WbtI}_{\mathrm{G} 191 \mathrm{~V}}:$ : pFNLTP/wbtI was determined as previously described (Inzana \& Anderson, 1985). Control tubes contained serum-sensitive A. pleuropneumoniae J45-100 in place of $F$. tularensis, or heat-inactivated PCS.

Survival in J774A.1 cells. Intracellular growth of the LVS, mutant $\mathrm{WbtI}_{\mathrm{G} 191 \mathrm{~V}}$ and the complemented mutant $\mathrm{WbtI}_{\mathrm{G} 191 \mathrm{~V}}:: \mathrm{pFNLTP} / w b t I$ was monitored in the murine macrophage-like cell line J774A.1 (American Type Culture Collection) by modification of published methods (Cowley \& Elkins, 2003). The number of bacteria added was confirmed by viable plate counting, and used at a m.o.i. of $50: 1$ (bacteria:macrophages). After $2 \mathrm{~h}$ incubation of $F$. tularensis with J774A. 1 cells at $37{ }^{\circ} \mathrm{C}$ in $5 \% \mathrm{CO}_{2}$, extracellular bacteria were removed by washing the cells with PBS, and the medium was replaced with $1 \mathrm{ml}$ complete Dulbeccos's Modified Eagle Medium (DMEM) plus $50 \mu \mathrm{g}$ gentamicin $\mathrm{ml}^{-1}$ to eliminate extracellular bacteria. After 45 min incubation, the cells were washed three times with PBS, followed by the addition of complete DMEM without antibiotics. The cells were incubated at $37{ }^{\circ} \mathrm{C}$ in $5 \% \mathrm{CO}_{2}$ for $72 \mathrm{~h}$ post-infection. The J774A.1 cells were washed in PBS and lysed by exposure to water for $3 \mathrm{~min}$, and serial dilutions of the lysate were plated on BHIBC agar to determine the number of intracellular bacteria at $0 \mathrm{~h}$ and at the indicated time points.

Virulence and immunoprotection studies in mice. To assess virulence, groups of five $\mathrm{BALB} / \mathrm{c}$ mice 6-8 weeks old (Jackson Laboratory) were challenged IP with various doses of exponentialphase LVS $\left(200,600\right.$ or 2000 c.f.u. per mouse), mutant $\mathrm{WbtI}_{\mathrm{G} 191 \mathrm{~V}}$ $\left(10^{3}, 10^{4}, 5 \times 10^{4}, 1.4 \times 10^{6}\right.$ or $2.8 \times 10^{7}$ c.f.u. per mouse) or complemented mutant $\mathrm{WbtI}_{\mathrm{G} 191 \mathrm{~V}}:: \mathrm{pFNLTP} / w b t I\left(10^{4}\right.$ c.f.u. per 
mouse) in $100 \mu \mathrm{l}$ PBS. IP inoculations were used to assess virulence because the LVS is most virulent to mice by this route (Fortier et al., 1991), and therefore this route is the greatest test for attenuation. For tissue-clearance studies, 3-5 mice were inoculated intranasally (IN) with $10^{7}$ c.f.u. per mouse of LVS, $\mathrm{WbtI}_{\mathrm{G} 191 \mathrm{~V}}$ or $\mathrm{WbtI}_{\mathrm{G} 191 \mathrm{~V}}$ : : pFNLTP/ $w b t I$ in $20 \mu \mathrm{l}$ PBS. IN challenge was also used because it is a natural but still severe challenge route (Conlan et al., 2003), and is a measure of the capability of a strain to disseminate. Mice were anaesthetized with mixed oxygen/isofluorane gas prior to inoculation. All inoculation doses were confirmed by viable plate counting on BHIBC agar. Animals exposed to the LVS or mutant strains were maintained and cared for in an accredited ABSL-2 facility. In some cases, mice were euthanized with excess $\mathrm{CO}_{2}$ at $2,4,8$ or 16 days postchallenge, and bacterial numbers in the spleen, liver and lung were determined following tissue homogenization, serial dilution and viable plate counting.

Mice were immunized either intradermally (ID) or IP followed by IP challenge, which was used because the $\mathrm{LD}_{50}$ of LVS for mice is lowest by the IP route (Fortier et al., 1991). For ID immunization, groups of five $B A L B / c$ mice each were inoculated with $100 \mu \mathrm{LVS}$ ( $10^{4}$ c.f.u.), mutant $\mathrm{WbtI}_{\mathrm{G} 191 \mathrm{~V}}\left(10^{5}\right.$ c.f.u.), complemented mutant $\mathrm{WbtI}_{\mathrm{G} 191 \mathrm{~V}}:$ :pFNLTP/wbtI $\left(10^{4}\right.$ c.f.u. $)$ or PBS alone. Fourteen days post-inoculation (PI), the mice were reimmunized with the same doses of the same strains, and 21 days later the mice were challenged IP with $25 \times \mathrm{LD}_{50}\left(3 \times 10^{3}\right.$ c.f.u. $), 75 \times \mathrm{LD}_{50}\left(9 \times 10^{3}\right.$ c.f.u. $)$ or $250 \times \mathrm{LD}_{50}\left(3 \times 10^{4} \quad\right.$ c.f.u. $)$ of the LVS parent strain $\left(\mathrm{LD}_{50}\right.$ $\sim 120$ c.f.u.). For IP immunization, groups of five BALB/c mice each were inoculated with $10^{3}, 10^{4}$ or $5 \times 10^{4}$ c.f.u. of the mutant in $100 \mu \mathrm{l}$ of PBS twice 2 weeks apart. Twenty-one days after the second immunization the mice were challenged IP with $75 \times \mathrm{LD}_{50}$ (groups immunized with $10^{3}$ or $10^{4}$ c.f.u. WbtI $\mathrm{I}_{\mathrm{G} 191 \mathrm{~V}}$ ) or $250 \times \mathrm{LD}_{50}$ (group immunized with $5 \times 10^{4}$ c.f.u. $\mathrm{WbtI}_{\mathrm{G} 191 \mathrm{~V}}$ ) of LVS. Each challenged animal was monitored for 21 days, and severely moribund mice were euthanized. Surviving mice were humanely euthanized using excess $\mathrm{CO}_{2}$, and select tissues cultured for the presence of bacteria, as described above.

Statistical analysis. The slope of the growth rate was determined from the formula:

$\frac{y_{2}-y_{1}}{x_{2}-x_{1}}$

where $y$ represents Klett units and $x$ represents time. Differences in susceptibility to serum or sodium deoxycholate were determined by Student's $t$ test. Attenuation of bacterial virulence and protective efficacy were determined by Fisher's exact test of $2 \times 2$ contingency tables. All statistical analyses were carried out using InStat software (Graphpad).

\section{RESULTS}

\section{Identification of LVS-specific genes involved in carbohydrate synthesis and generation of an LPS mutant}

Following the use of SSH to identify LVS-specific genes, one gene $(w b t B)$ was identified in a $17.4 \mathrm{~kb}$ region consisting of 15 carbohydrate biosynthesis genes (later determined to be the O-antigen locus), and was selected for allelic replacement with plasmid pFA501 (see Methods). However, PCR and Southern blotting of genomic DNA from these mutants indicated that $w b t B$ was still present in the genome (data not shown). To determine if another gene in this region had mutated, $23 \mathrm{~kb}$ of DNA from both mutants was sequenced, which included the entire $\mathrm{O}$ antigen locus. From this analysis it was determined that the two isolates differed from the parent by only a single nucleotide substitution in $w b t I$, a sugar transaminase/ perosamine synthetase, required for biosynthesis of 4,6dideoxy-4-formamido-D-glucose (Prior et al., 2003). A $\mathrm{C} \rightarrow \mathrm{A}$ transversion in mutant $\mathrm{WbtI}_{\mathrm{S} 187 \mathrm{Y}}$ caused a codon change of TCT $\rightarrow$ TAT, resulting in the change of Ser to Tyr in residue 187. A $\mathrm{G} \longrightarrow \mathrm{T}$ transversion in mutant $\mathrm{WbtI}_{\mathrm{G} 191 \mathrm{~V}}$ causing a codon change of GGT $\rightarrow$ GTT resulted in residue 191 changing from Gly to Val. The wbtI gene from the LVS was amplified and sequenced, and neither of the substitutions found in the mutants was present in the parent strain. Aligning the amino acid sequence of LVS WbtI with its homologues from 25 species/subspecies indicated that Gly191 was highly conserved in all 25 enzymes (data not shown). Therefore, the phenotype of mutant $\mathrm{WbtI}_{\mathrm{G} 191 \mathrm{~V}}$ and its virulence in mice were further characterized.

\section{Computational structural modelling}

The locations of residues Ser187 and Gly191 in WbtI were computationally investigated, as were the effects of S187Y and G191V mutations on enzyme structure (data not shown). Both residues were in the core of the WbtI sugar transamine/perosamine synthetase. The alteration of S187Y or G191V changed the number of $\alpha$-helices, $\beta$-sheets and turns of the enzyme, which would result in substantial conformational changes, suggesting that $\mathrm{WbtI}_{\mathrm{S} 187 \mathrm{Y}}$ and $\mathrm{WbtI}_{\mathrm{G} 191 \mathrm{~V}}$ had lost biological activity.

\section{Physical and chemical characterization of LPS}

Since the mutation in $\mathrm{WbtI}_{\mathrm{G} 191 \mathrm{~V}}$ was predicted to be in the $\mathrm{O}$-antigen region, purified LPS samples from $\mathrm{WbtI}_{\mathrm{G} 191 \mathrm{~V}}$ and the parent were separated by electrophoresis and immunoblotted with rabbit polyclonal antiserum to LVS (Fig. 1a) or murine mAb to LPS O antigen (Fig. 1b). A characteristic ladder-like pattern was observed with LVS LPS reacted with both LVS antiserum and $\mathrm{mAb}$, but this pattern was absent from WbtI $_{\text {G191v }}$ LPS incubated with either antibody. However, immunoreactive low-molecularmass material was present in mutant LPS blotted with LVS antiserum, but not with $\mathrm{mAb}$ to $\mathrm{O}$ antigen, suggesting that the core, but not the $\mathrm{O}$ antigen, was present in the mutant. Furthermore, unlike the parental LPS, there was no ladderlike pattern in the LPS of $\mathrm{WbtI}_{\mathrm{G} 191 \mathrm{~V}}$ on polyacrylamide gels stained with Emerald Q fluorescent stain (data not shown). LVS LPS $\mathrm{O}$ antigen has been shown to undergo antigenic phase variation to an $F$. novicida $\mathrm{O}$ antigen, resulting in a switch from reactivity to LVS O-antigen antibodies to reactivity with $F$. novicida $\mathrm{O}$-antigen antibodies (Cowley et al., 1996). However, neither LVS LPS nor $\mathrm{WbtI}_{\mathrm{G} 191 \mathrm{~V}} \mathrm{O}$ antigen reacted with antiserum to $F$. novicida strain U112 in a Western blot, indicating that the mutant did not 


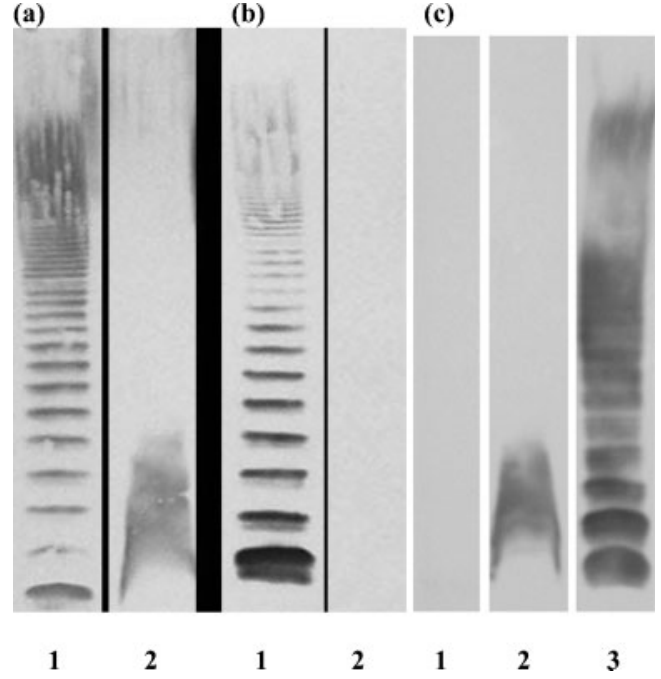

Fig. 1. Western blots of LPS from the LVS and Wbtl $\mathrm{G} 191 \mathrm{v}_{\text {mutant. }}$ Purified LPS $(20 \mu \mathrm{g})$ was separated by SDS-PAGE, transferred to nitrocellulose, and blotted with (a) a 1:1000 dilution of rabbit polyclonal antiserum to LVS, (b) 1:10 mouse mAb to LVS O antigen, or (c) 1:1000 dilution of antiserum to $F$. novicida. Production of antiserum and blot development were as described in Methods. The ladder-like pattern of LPS from mutant Wbtl $\mathrm{G} 191 \mathrm{~V}_{\mathrm{V}}$ was absent in all blots, indicating a loss of $\mathrm{O}$ antigen and not phase variation. LVS LPS reacted with antiserum to whole LVS cells and $\mathrm{mAb}$ to $\mathrm{O}$ antigen. Only low-molecular-mass LPS from Wbtl $_{\text {G191v }}$ reacted with antisera to both LVS and $F$. novicida whole cells, indicating conservation of core epitopes. The lack of any reactivity of LVS LPS with antiserum to F. novicida suggested that $\mathrm{O}$-antigen epitopes blocked binding to the conserved LPS

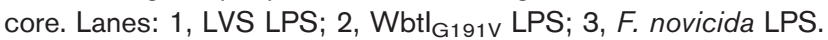

contain a $F$. novicida-reactive $\mathrm{O}$ antigen. The reactivity of low-molecular-mass LPS from mutant $\mathrm{WbtI}_{\mathrm{G} 191 \mathrm{~V}}$ with $F$. novicida antiserum indicated conservation of core LPS epitopes between the mutant and $F$. novicida. The lack of reactivity of low-molecular-mass LVS LPS with F. novicida antiserum was probably due to steric interference of core epitopes by $\mathrm{O}$ antigen, further supporting the suggestion that the LPS of $\mathrm{WbtI}_{\mathrm{G} 191 \mathrm{~V}}$ lacked $\mathrm{O}$ antigen (Fig. 1c).

The glycosyl composition and structure of purified LPS was analysed by combined GC/MS and MALDI-MS, respectively. The $\mathrm{mol} \%$ of total carbohydrate for mannose, glucose, $\mathrm{N}$-acetylgalactosamine, $\mathrm{N}$-acetylglucosamine and 3-deoxy-D-manno-2 octulosonic acid, which are components of the core oligosaccharide, were comparable in the LPS of the LVS parent and $\mathrm{WbtI}_{\mathrm{G} 191 \mathrm{~V}}(17 \pm 1,33 \pm 3,5 \pm 1$, $15 \pm 5$ and $23 \pm 3$, respectively). However, the O-antigenspecific glycose $\mathrm{N}$-acetyl quinovosamine (QuiNAc) was not detected in $\mathrm{WbtI}_{\mathrm{G} 191 \mathrm{~V}} \mathrm{LPS}$, confirming that the $\mathrm{O}$ antigen was not present in the mutant. The presence of a complete core structure (Vinogradov et al., 2002) in $\mathrm{WbtI}_{\mathrm{G} 191 \mathrm{~V}}$, but no $\mathrm{O}$ antigen, was confirmed by MALDI-MS (Fig. 2; details in the legend).

\section{Complementation}

To confirm that the mutation in wbtI was solely responsible for the loss of $\mathrm{O}$ antigen in $\mathrm{WbtI}_{\mathrm{G} 191 \mathrm{~V}}$, a normal copy of wbtI was amplified and cloned into shuttle vector pFNLTP6 alone and behind the groE promoter, and each construct was electroporated into $\mathrm{WbtI}_{\mathrm{G} 191 \mathrm{~V}}$. The presence of the plasmid in recombinant clones was confirmed by gel electrophoresis and PCR. Western blots of extracted LPS from the parent strain, the mutant containing pFNLTP6 alone, and mutants containing pFNLTP6/wbtI, showed that the wbtI gene in trans with or without the $g r o E$ promoter complemented the mutation and restored normal LPS O-antigen production (Fig. 3).

\section{Growth rate}

To assess whether the mutation in $\mathrm{WbtI}_{\mathrm{G} 191 \mathrm{~V}}$ affected its growth rate, the mutant, parental and complemented strains were inoculated in BHIC broth at a cell density of 55 Klett units, and the $\mathrm{OD}_{600}$ was monitored for $8 \mathrm{~h}$, by which time all strains had reached stationary phase. The growth rates of $\mathrm{WbtI}_{\mathrm{G} 191 \mathrm{~V}}$, the LVS parental strain and complemented mutant $\mathrm{WbtI}_{\mathrm{G} 191 \mathrm{~V}}:: \mathrm{pFNLTP} /$ wbtI were highly similar, with a growth-rate slope of about 0.6 for each (data not shown).

\section{Serum bactericidal assay}

The parental LVS and complemented mutant $\mathrm{WbtI}_{\mathrm{G} 191 \mathrm{~V}}:: \mathrm{pFNLTP} / w b t I$ were completely resistant to the bactericidal action of fresh PCS up to at least $40 \%(\mathrm{v} / \mathrm{v})$. The LVS (as well as our type A strains Schu S4 and TI0902) and the complemented mutant were also resistant to at least $40 \%$ PCS supplemented with $40 \%$ hyperimmune rabbit serum made to irradiated LVS (data not shown). However, mutant strain $\mathrm{WbtI}_{\mathrm{G} 191 \mathrm{~V}}$ was completely killed by $<3 \%$ fresh PCS only, and was much more sensitive to PCS than a non-encapsulated $A$. pleuropneumoniae control strain. Of interest was that serum susceptibility increased sharply from essentially no killing in $0.5 \%$ PCS to $>80 \%$ killing in $1 \%$ PCS (Fig. 4). Similar results were obtained when mouse, canine or human sera were used (data not shown).

\section{Intracellular survival in J774A.1 cells}

Following infection of the J774A.1 macrophage-like cell line with LVS there was continuous exponential growth over the study period of $72 \mathrm{~h}$. Mutant $\mathrm{WbtI}_{\mathrm{G} 191 \mathrm{v}}$ grew slowly but continuously during the first $48 \mathrm{~h}$, but the growth rate increased dramatically after $48 \mathrm{~h}$. Complemented mutant $\mathrm{WbtI}_{\mathrm{G} 191 \mathrm{~V}}:: \mathrm{pFNLTP} / w b t I$ grew somewhat faster and in parallel to that of the mutant throughout the time period, but not as rapidly as the parental strain after the initial $24 \mathrm{~h}$ (Fig. 5). 

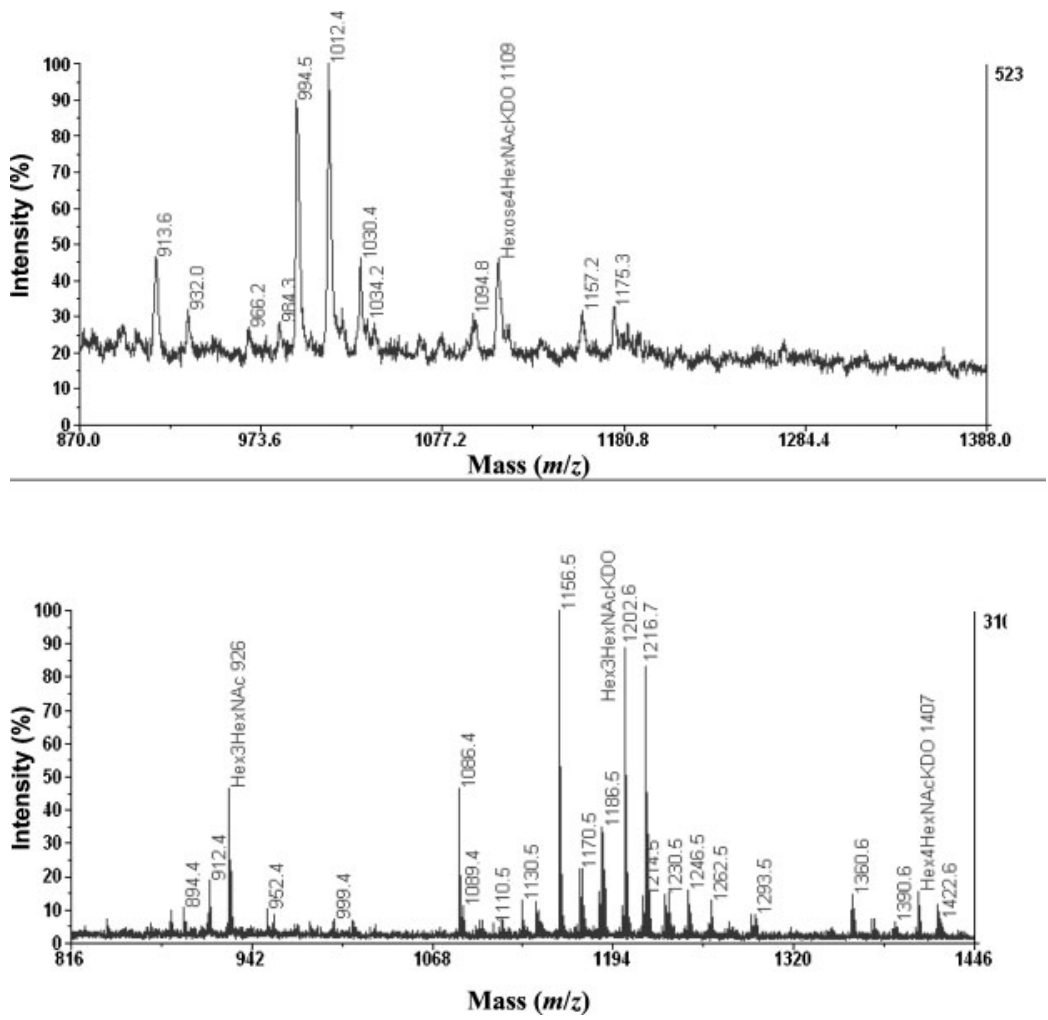

Fig. 2. Analysis of mutant $\mathrm{Wbtl}_{\mathrm{G} 191 \mathrm{~V}} \mathrm{LPS}$ by MALDI-MS. The upper panel represents analysis of unmethylated oligosaccharide core. The peak at $m / z 1109$ is consistent with a core containing a 2-keto-3-deoxyoctonic acid (3deoxy-D-manno-2-octulosonic acid) (KDO) residue, four hexoses and one $N$-acetylhexosamine. There are also peaks at 14 amu below and 162 amu above this peak, which would be consistent with replacement of the acetyl group on hexosamine with a formyl group and addition of one hexose unit, respectively. The peaks at $\mathrm{m} / \mathrm{z} 1012$ and 1175 also represent a difference of one hexose unit and have corresponding peaks 18 amu lower than themselves, which would be consistent with loss of water. These may represent breakdown products of the core. The lower panel represents MALDI-MS of oligosaccharide core methylated twice. Methylation of the sample results in a shift from $\mathrm{m} / \mathrm{z} 1109$ to 1407 . Breakdown products corresponding to loss of water, methanol and a $30 \mathrm{amu}$ species were also observed in the KDO-containing oligosaccharides, as expected. Note that loss of KDO during MS eliminates these companion peaks from the $\mathrm{m} / \mathrm{z} 926$ species.

\section{Sensitivity to deoxycholate}

F. novicida mutants defective in LPS biosynthesis may have decreased or increased sensitivity to the detergent sodium deoxycholate (Cowley et al., 2000). Therefore, the sensitivity of $\mathrm{WbtI}_{\mathrm{G} 191 \mathrm{~V}}$ incubated with various concentrations of sodium deoxycholate in PBS for 45 min was examined (Fig. 6). On average, in the presence of $0.1 \%$ deoxycholate, more than $100 \%$ of $\mathrm{WbtI}_{\mathrm{G} 191 \mathrm{~V}}$ cells survived (indicating growth of the bacteria during the incubation period), whereas fewer than $60 \%$ of the LVS parental strain cells survived $(P=0.02)$. When the sodium deoxycholate concentration was increased to $1 \%$, essentially all LVS cells were killed, but $12.4 \%$ of $\mathrm{WbtI}_{\mathrm{G} 191 \mathrm{~V}}$ cells remained viable. Moreover, up to $4.4 \%$ of $\mathrm{WbtI}_{\mathrm{G} 191 \mathrm{v}}$ mutant cells were able to tolerate up to $10 \%$ deoxycholate. Complemented mutant $\mathrm{WbtI}_{\mathrm{G} 191 \mathrm{~V}}: \mathrm{pFNLTP} / w b t I$ was intermediate between the LVS and the mutant in sensitivity to $0.01 \%$ and $0.1 \%$ deoxycholate, but was as susceptible as the parent at concentrations of deoxycholate of $1 \%$ or more.

\section{Virulence of Wbtl G191v $_{\text {to }}$ mice}

The mouse IP $\mathrm{LD}_{50}$ for our strain of LVS was previously determined to be about 120 c.f.u. (Inzana et al., 2004). For this study, mice were inoculated IP with doses of LVS, mutant $\mathrm{WbtI}_{\mathrm{G} 191 \mathrm{~V}}$ or complemented mutant $\mathrm{WbtI}_{\mathrm{G191 \textrm {V }}}:: \mathrm{pFNLTP} / w b t I$ that ranged from 200 to
$2.8 \times 10^{7}$ c.f.u. (Table 2). Clinical symptoms were not detected in any of the mice until about $48 \mathrm{~h}$ PI, by which time mice inoculated with 2000 c.f.u. LVS had ruffled fur, were inactive and appeared lethargic. All the mice inoculated with this dose of the parental strain died between 4 and 5 days PI. Mice inoculated with lower doses of the parental strain had ruffled fur and were lethargic at 72 h PI. By 6 days PI, all mice inoculated with 600 c.f.u. LVS had died, and three of five mice inoculated with 200 c.f.u. LVS died by 7 days PI. However, by 14 days PI all mice inoculated IP with up to $2.8 \times 10^{5}$ c.f.u. mutant $\mathrm{WbtI}_{\mathrm{G} 191 \mathrm{~V}}$ remained clinically normal. Mice infected with the two highest doses of the mutant $\left(1.4 \times 10^{6}\right.$ and 2 . $8 \times 10^{7}$ c.f.u.) showed some early clinical symptoms, such as ruffled fur, stressed breathing and hunched gait, but recovered completely. Mice challenged with $10^{4}$ c.f.u. complemented mutant $\mathrm{WbtI}_{\mathrm{G} 191 \mathrm{~V}}:$ : $\mathrm{pFNLTP} / w b t I$ became moribund within 2 days and died by 4 days PI.

Clearance of the LVS, mutant $\mathrm{WbtI}_{\mathrm{G} 191 \mathrm{~V}}$ and complemented mutant from the tissues of challenged mice was evaluated following IN inoculation with $10^{5}$ c.f.u. of each strain. At $48 \mathrm{~h}$ PI there were about 2-3 logs fewer cells of mutant $\mathrm{WbtI}_{\mathrm{G} 191 \mathrm{~V}}$ in the tissues of mice than cells of the parental LVS, although none of the mice appeared ill. Thus, IN challenge was less severe than IP challenge for these mice. The number of complemented mutant cells in the lungs was similar to that of the mutant, probably because the challenge route was IN, but the numbers of the 


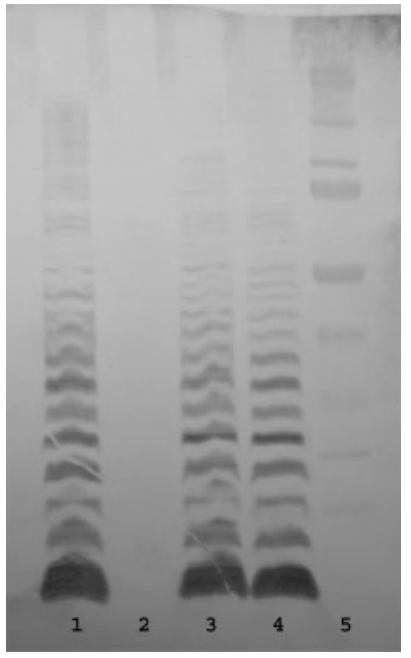

Fig. 3. Western blot of LPS from complemented mutant Wbtl G191v $_{\text {: }}$ pFNLTP/wbtl. A normal copy of wbt/ was amplified by PCR and its sequence confirmed, and it was then cloned into pFNLPT6 with and without the groE promoter. Each strain was grown on BHIBC and the LPS extracted by a micro-phenol/water procedure for SDS-PAGE analysis (Inzana, 1983). Samples (5 $\mu$ l) of LPS extract were applied to each lane, followed by electrophoresis and Western blotting with rabbit antiserum to LVS. Lanes:

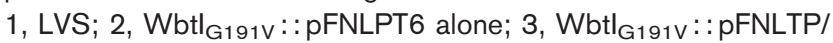
wbt/ without the groE promoter; 4, Wbtl $\mathrm{G}_{191 \mathrm{~V}}:$ : pFNLTP/wbt/ with the groE promoter; 5 , molecular weight standards.

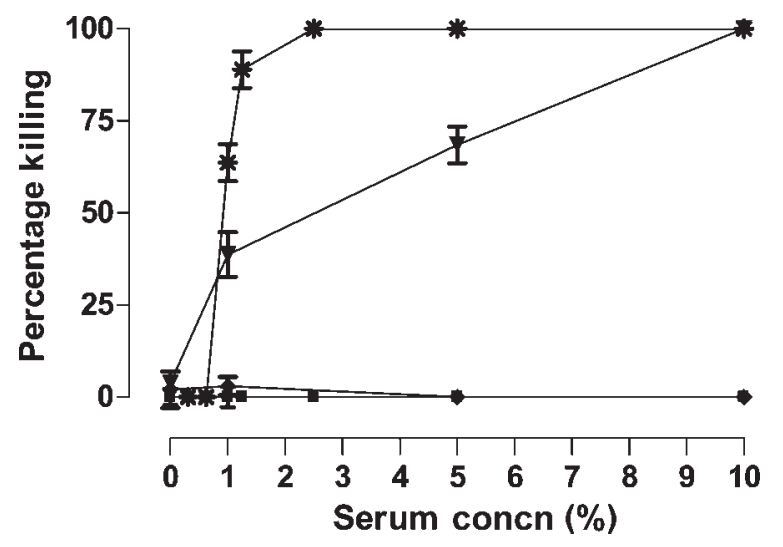

Fig. 4. Complement-mediated killing of F. tularensis in PCS. Values shown are percentage killing of $F$. tularensis or nonencapsulated control strain $A$. pleuropneumoniae J45-100 in various dilutions of PCS after 60 min incubation at $37{ }^{\circ} \mathrm{C}$. (ם) LVS parent strain; $\left(^{*}\right)$ mutant strain Wbtl ${ }_{\text {G191V; }}(\boldsymbol{})$ complemented mutant $\mathrm{Wbtl}_{\mathrm{G} 191 \mathrm{~V}}$ : :pFNLTP/wbtl; ( $)$ serum-susceptible control strain $A$. pleuropneumoniae J45-100. Each point represents the mean of three experiments. Where error bars are not visible, the SEM was less than $1 \%$.

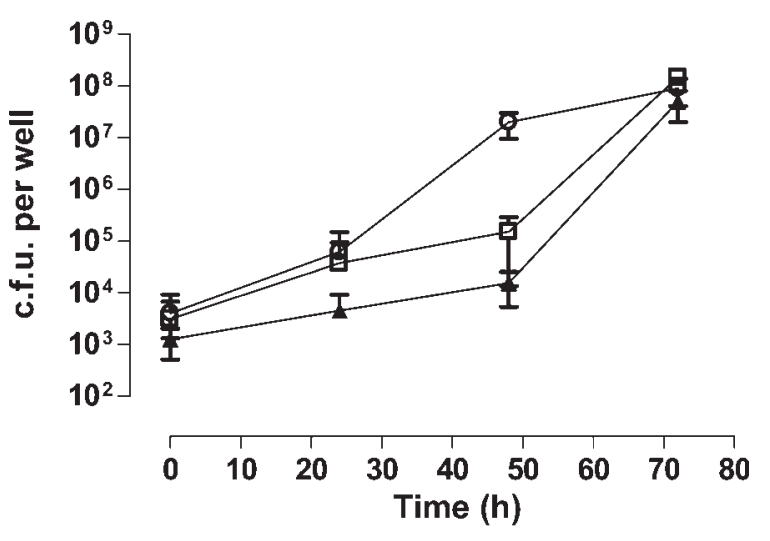

Fig. 5. Intracellular growth of $F$. tularensis in J774A.1 cells. The J774A.1 monolayer was infected with LVS, mutant strain Wbtl $_{\text {G191V }}$ or complemented strain Wbtl G191V $_{\text {: }}$ pFNLTP/wbtl, and intracellular bacterial growth was monitored up to $72 \mathrm{~h}$ post-infection, as described in Methods. Data are shown on a log scale as the average number of bacteria recovered from dilutions of lysates of J774A.1 cells. The results shown were from a single experiment with samples tested in triplicate at each time point. Identical experiments were repeated on at least two other days with similar results. $(\bigcirc)$ LVS; $(\boldsymbol{\Delta})$ mutant strain Wbtl $_{\mathrm{G} 191 \mathrm{~V}}$; $(\square)$ complemented mutant strain $\mathrm{Wbtl}_{\mathrm{G} 191 \mathrm{~V}}:$ : pFNLTP/wbtl.

complemented mutant strain were more similar to those of the parental strain in the liver and spleen. From 2 days post-challenge to 4 days post-challenge the number of

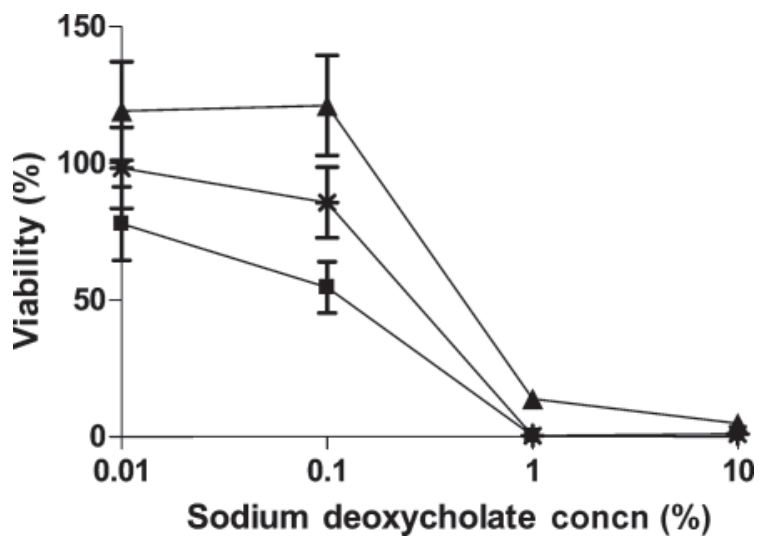

Fig. 6. Susceptibility of $F$. tularensis parental and mutant strains to various concentrations of sodium deoxycholate. Bacteria were suspended in microtitre wells at $5 \times 10^{5}$ c.f.u. in $100 \mu \mathrm{l}$ and an equal volume of sodium deoxycholate was added to the final concentrations indicated. Aliquots were plated at $0 \mathrm{~min}$ and again after $45 \mathrm{~min}$ incubation at $37{ }^{\circ} \mathrm{C}$. Results shown are from a single experiment with each strain tested in triplicate, but identical experiments with similar results were done on three other separate occasions. The $120 \%$ survival of $\mathrm{Wbtl}_{\mathrm{G} 191 \mathrm{~V}}$ was due to growth of the bacteria during the $45 \mathrm{~min}$ incubation period. SDs of less than $1 \%$ are not visible. ( $\boldsymbol{\square})$ LVS; $(\boldsymbol{\Delta})$ mutant strain $\mathrm{Wbtl}_{\mathrm{G} 191 \mathrm{~V}} ;\left(^{*}\right)$ complemented strain Wbtl $_{\mathrm{G} 191 \mathrm{~V}}$ : : pFNLTP/wbtl. 
Table 2. Virulence of LVS and $\mathrm{Wbtl}_{\mathrm{G} 191 \mathrm{~V}}$ in $\mathrm{BALB} / \mathrm{c}$ mice ND, Not determined.

\begin{tabular}{|lcc|}
\hline Challenge dose IP (c.f.u)* & \multicolumn{2}{c|}{$\begin{array}{c}\text { Dead/total number } \\
\text { of mice } \dagger\end{array}$} \\
\cline { 2 - 3 } & LVS & WbtI $_{\text {G191V }}$ \\
\hline 200 & $3 / 5$ & $0 / 5$ \\
600 & $5 / 5$ & $0 / 5$ \\
$2 \times 10^{3}$ for LVS; $10^{3}$ for WbtI $\mathrm{Gl}_{\mathrm{G} 191 \mathrm{~V}}$ & $5 / 5$ & $0 / 5$ \\
$1 \times 10^{4}$ & $\mathrm{ND}$ & $0 / 5$ \\
$5 \times 10^{4}$ & $\mathrm{ND}$ & $0 / 5$ \\
$2.8 \times 10^{5}$ & $\mathrm{ND}$ & $0 / 5$ \\
$1.4 \times 10^{6}$ & $\mathrm{ND}$ & $0 / 5$ \\
$2.8 \times 10^{7}$ & $\mathrm{ND}$ & $0 / 5$ \\
\hline
\end{tabular}

${ }^{\star}$ The $\mathrm{LD}_{50}$ was determined to be $\sim 120$ c.f.u. for the LVS challenge strain IP.

$\dagger$ Challenged mice were carefully observed for 21 days PI. All mice challenged with LVS showed clinical symptoms (ruffled fur, inactivity, refusal to eat) by $48-72 \mathrm{~h}$ PI. Only two mice challenged with $1.4 \times 10^{6}$ c.f.u. and three mice challenged with $2.8 \times 10^{7}$ c.f.u. of mutant $\mathrm{WbtI}_{\mathrm{G} 191 \mathrm{~V}}$ showed similar clinical symptoms, but completely recovered by 5 days PI.

WbtI $_{\mathrm{G} 191 \mathrm{v}}$ cells had dropped by about 1 log in all tissues, whereas the numbers of the parental strain had increased by about $1 \log$ in the lungs and by more than 3 logs in the spleen. The numbers of the complemented mutant increased about $1 \log$ in all tissues; these animals were now moribund (Fig. 7). Mice challenged with the parental and complemented mutant $\mathrm{WbtI}_{\mathrm{G} 191 \mathrm{~V}}:$ :pFNLTP/wbtI died or were euthanized by the fifth day PI, whereas by 8 days post-challenge all the mice challenged with $\mathrm{WbtI}_{\mathrm{G} 191 \mathrm{~V}}$ appeared normal and had cleared the bacteria from all of their tissues (data not shown).

\section{Immunoprotective capacity of $\mathbf{W b t l}_{\mathrm{G} 191 \mathrm{v}}$ for mice}

Mice were immunized either ID or IP with mutant $\mathrm{WbtI}_{\mathrm{G} 191 \mathrm{~V}}$ to assess whether the mutant could confer protection against subsequent IP challenge with LVS. For ID immunization, three groups of five mice each were vaccinated with $10^{5}$ c.f.u. WbtIG191V without adjuvant twice, 2 weeks apart; control groups were inoculated with PBS alone or $10^{4}$ c.f.u. LVS. Three weeks after the second immunization mice in each group were challenged IP with various doses of LVS, as described in Methods, and monitored for up to 21 days. The mice immunized with the mutant made a strong antibody response to LVS whole cells, but a relatively weak response to purified LVS LPS (data not shown), which was expected given that the mutant lacked $\mathrm{O}$ antigen. All five mice in the PBS control group challenged with $25 \times \mathrm{LD}_{50}$ LVS died, whereas none of the mice immunized with LVS then challenged with $250 \times \mathrm{LD}_{50}$ of the same strain died (not shown). None of the five mice immunized with $\mathrm{WbtI}_{\mathrm{G} 191 \mathrm{~V}}$ and subsequently challenged with $25 \times \mathrm{LD}_{50}$ LVS died. However, two and three out of five mice immunized with the mutant and later challenged with 75 or $250 \times \mathrm{LD}_{50}$ LVS, respectively, died (Fig. 8a). About 3 days post-challenge, the surviving animals developed some clinical symptoms, but later recovered.

For IP immunization, three groups of five mice each were vaccinated with $10^{3}, 10^{4}$ or $5 \times 10^{4}$ c.f.u. $\mathrm{WbtI}_{\mathrm{G} 191 \mathrm{~V}}$ twice 2 weeks apart. Three weeks after the second immunization the mice were challenged IP with various doses of LVS, as

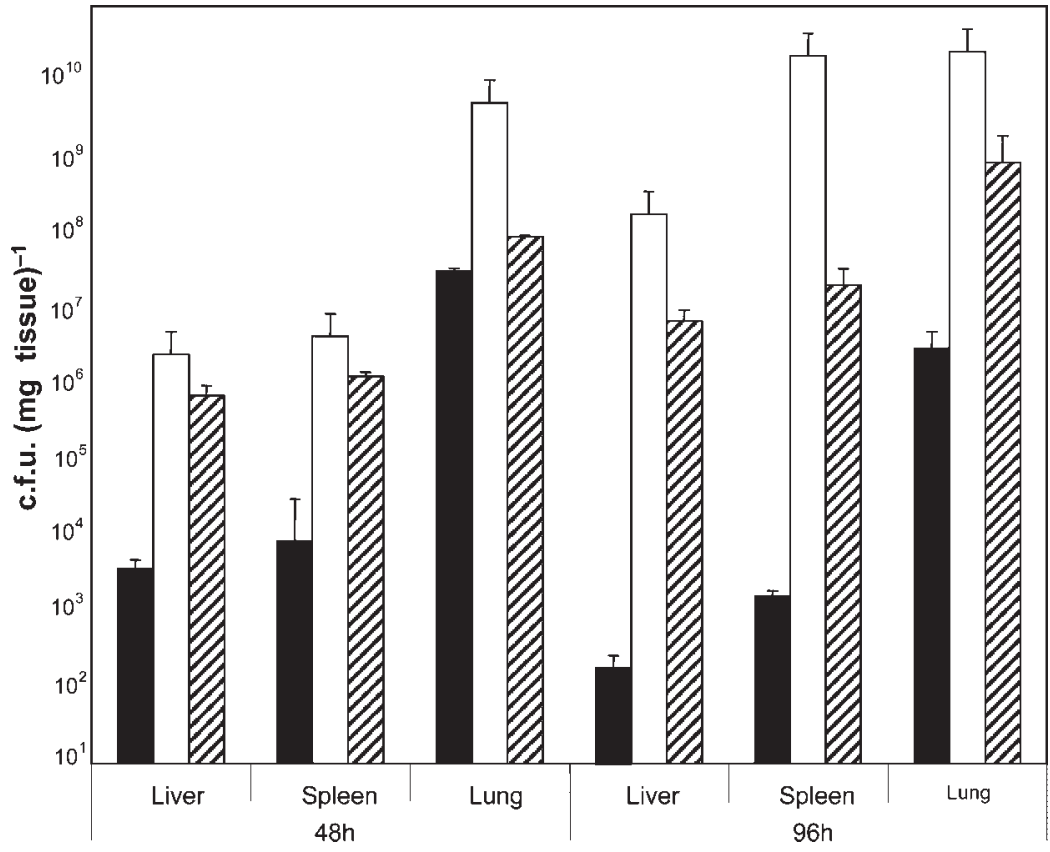

Fig. 7. Clearance of $F$. tularensis from the tissues of mice following IN inoculation. Surviving mice were euthanized at 48, 96 and $192 \mathrm{~h} \mathrm{PI}$ (the last time is not shown). The lung, liver and spleen were aseptically removed and homogenized in PBS, and the c.f.u. (mg tissue $)^{-1}$ was determined. By 5 days PI all mice challenged with $10^{5}$ c.f.u. LVS or complemented mutant Wbtl $_{\text {G191V }}:$ :pFNLTP/wbtl died or needed to be euthanized. By 8 days PI all mice challenged with $10^{5}$ c.f.u. Wbtl $\mathrm{G}_{191 \mathrm{~V}}$ were clinically normal and no bacteria were found in any of the tissues. Therefore, only results through to day 4 are shown. Filled bars, mutant $\mathrm{Wbtl}_{\mathrm{G191}}$; open bars, LVS; hatched bars, complemented mutant $\mathrm{Wbtl}_{\mathrm{G} 191 \mathrm{~V}}$ : pFNLTP/wbtl. 
(a)

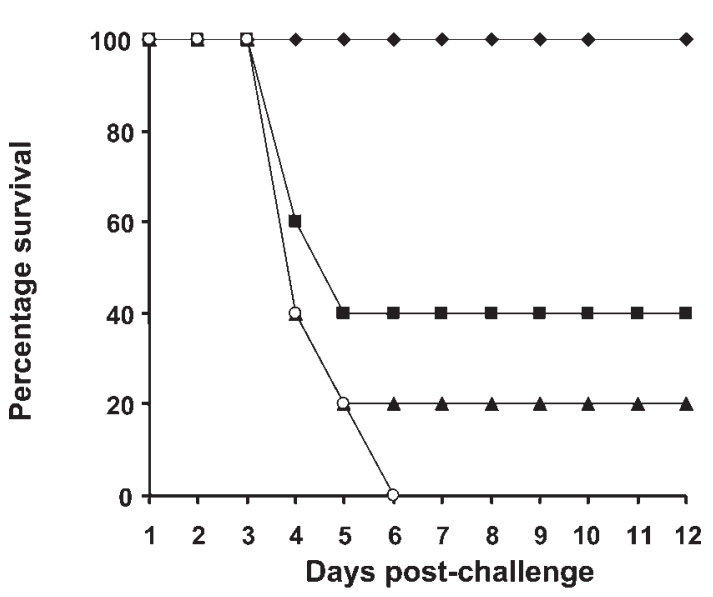

(b)

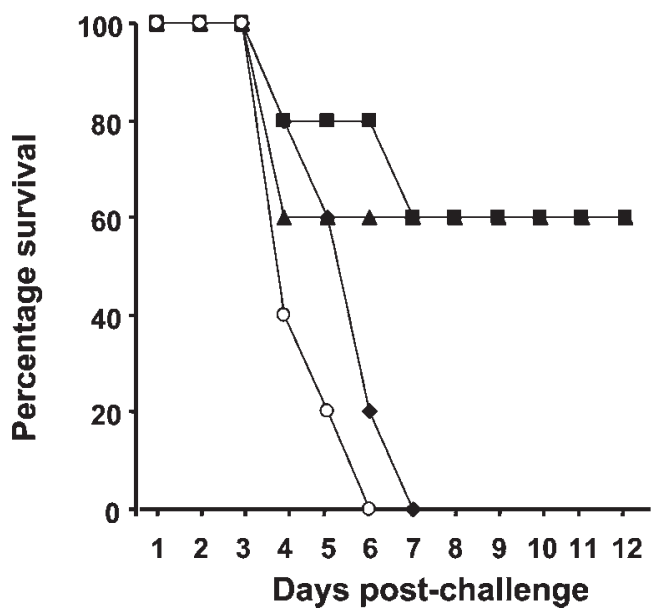

Fig. 8. Immunoprotection of BALB/c mice against LVS IP challenge following immunization with $\mathrm{Wbtl}_{\mathrm{G} 191 \mathrm{~V}}$. (a) Groups of five mice each were immunized ID with $10^{5}$ c.f.u. Wbtl G191v $_{\text {or buffer }}$ twice, 2 weeks apart, followed by IP challenge with the indicated doses of LVS 3 weeks after the second immunization. $(\bigcirc)$ Control mice inoculated with PBS only and challenged with $25 \times \mathrm{LD}_{50} ;(\boldsymbol{)})$ immunized mice challenged with $25 \times \mathrm{LD}_{50}$ [protection was highly significant $(P=0.004)$ ]; ( $\mathbf{(})$ immunized mice challenged with $75 \times$ $\mathrm{LD}_{50}$; ( $\boldsymbol{\Delta}$ ) immunized mice challenged with $250 \times \mathrm{LD}_{50}$. (b) Groups of five mice each were immunized IP with $10^{3}, 10^{4}$ or $5 \times 10^{4}$ c.f.u. Wbtl ${ }_{\text {G191V }}$ twice, 2 weeks apart, followed by IP challenge with LVS 3 weeks after the second immunization. $(\bigcirc)$ Control mice inoculated with PBS only and challenged with $25 \times \mathrm{LD}_{50} ;(\boldsymbol{)})$ mice immunized with $10^{3}$ c.f.u. followed by challenge with $75 \times \mathrm{LD}_{50} ;(\boldsymbol{\square})$ mice immunized with $5 \times 10^{4}$ c.f.u. and challenged with $75 \times \mathrm{LD}_{50}(P=0.083) ;(\boldsymbol{\Lambda}) 5 \times 10^{4}$ c.f.u.-immunized mice challenged with $250 \times \mathrm{LD}_{50}(P=0.083)$. Following challenge mice were monitored for 12 days. Mice that appeared to be severely moribund were euthanized and counted as dead.

described in Methods. All five mice immunized with $10^{3}$ c.f.u. $\mathrm{WbtI}_{\mathrm{G} 191 \mathrm{~V}}$ and subsequently challenged with $75 \times$ $\mathrm{LD}_{50}$ LVS died. However, three of five mice immunized with $10^{4}$ c.f.u. mutant $\mathrm{WbtI}_{\mathrm{G} 191 \mathrm{v}}$ and later challenged with $75 \times \mathrm{LD}_{50}$ LVS survived. Similarly, three of five mice immunized with $5 \times 10^{4}$ c.f.u. mutant and later challenged with $250 \times \mathrm{LD}_{50}$ LVS survived (Fig. 8b). The surviving mice in this group developed clinical symptoms by day 2 postchallenge, but later recovered. Controls were not immunized IP with LVS because the lethal dose of LVS for mice is low by this route (some mice die from as few as 10 cells).

\section{DISCUSSION}

The virulence factors and biology of $F$. tularensis are not well characterized. One approach to identify such virulence factors is to identify genes present in virulent $F$. tularensis that are absent or have low homology to genes in closely related F. novicida. SSH has been used to successfully identify virulence genes present in pathogens that are absent in closely related species (Bernier \& Sokol, 2005; DeShazer et al., 2001; Harakava \& Gabriel, 2003; Liu et al., 2003; Newton et al., 2006; Parsons et al., 2003; Winstanley, 2002), and was therefore used to identify genes uniquely expressed by the more virulent type A and B strains. Seventy-six LVS-specific genes with hypothetical or known functions were identified in eight genomic regions in multiple SSH clones (Ahmed \& Inzana, 2004). A putative glycosyl transferase in region VII was chosen for deletion due to its homology to a polysaccharide-biosynthesis gene. This gene was later identified as $w b t B$, and genomic region VII as the $\mathrm{O}$-antigen locus.

Attempts to knock out $w b t B$ using the $s a c B-\mathrm{Cm}^{\mathrm{R}}$ cassette in vector $\mathrm{pPV}$ resulted in the cointegration of the $s a c B$ $\mathrm{Cm}^{\mathrm{R}}$ gene, as determined by PCR amplification of plasmid DNA from the genome. However, excision of the cointegrant in the presence of sucrose apparently resulted in religation of the original sequence without deletion of $w b t B$, as PCR and Southern blotting indicated a single, normal copy of $w b t B$ in the genome, but no evidence of plasmid DNA in the genome. Nonetheless, screening of sucrose-resistant strains for lack of iridescence and a darkred phenotype on Congo red agar (characteristic of $F$. novicida, but not type A or B strains) resulted in the identification of two LVS mutant strains both containing single-residue ( $\mathrm{S} 187 \mathrm{Y}$ and G191V) changes in WbtI, as determined by sequencing the O-antigen locus. The G191V mutation in wbtI was confirmed by complementation in trans with a normal copy of the gene, which restored Oantigen synthesis, resistance to the bactericidal action of serum, enhanced susceptibility to sodium deoxycholate, and virulence in mice. Of interest was that complementation occurred in the presence and absence of the groE promoter upstream of $w b t I$, indicating that a promoter in the plasmid was also likely driving expression of wbtI.

A single amino acid substitution in MglA has been reported to cause the loss of intramacrophage survival and growth of $F$. novicida (Baron \& Nano, 1998). A similar residue alteration appeared to affect the enzymic function 
of WbtI. Comparative computational modelling showed that Ser197 and Gly191 were both in the core of the wildtype enzyme, and that the side atoms of these residues extended into the milieu. Gly is the smallest and the most flexible amino acid residue. Substitutions or deletions of Gly residues can cause steric hindrance, block the necessary conformational changes in bacterial enzymes, and affect enzyme activity (Li \& Rosen, 1998; Li et al., 2000). The wbtI gene is proposed to be a sugar transaminase/perosamine synthetase, required for biosynthesis of 4,6-dideoxy-4formamido-D-glucose (Prior et al., 2003). Therefore, mutagenesis of this gene should result in complete loss of $\mathrm{O}$ antigen, which was confirmed by MALDI-MS analysis. It is not clear why attempts to mutate $w b t B$ resulted in mutations in wbtI. However, the $5^{\prime}$ and $3^{\prime}$ ends of the Oantigen locus were found to be bordered by the transposase and pseudotransposase IS sequences isftu2 and isftu1, respectively. The presence of these IS sequences may cause the $\mathrm{O}$-antigen locus to be a hypermutable region, resulting in loss of $\mathrm{O}$ antigen (the grey colony variant; Hartley et al., 2005), or phase variation to a F. novicida-type $\mathrm{O}$ antigen (Cowley et al., 1996).

The loss of polysaccharide capsule or $\mathrm{O}$ antigen commonly enhances the susceptibility of Gram-negative bacteria to the bactericidal action of serum (Joiner, 1988). As expected, $\mathrm{WbtI}_{\mathrm{G} 191 \mathrm{~V}}$ was completely killed by fresh $3 \%$ PCS, which lacks antibody, but is rich in complement. In contrast, the parent and complemented mutant were completely resistant to killing by a high concentration of PCS, even in the presence of hyperimmune rabbit serum. Thus, the LPS $\mathrm{O}$ antigen is essential to $F$. tularensis for resistance to the bactericidal activity of serum, and therefore virulence. However, $\mathrm{WbtI}_{\mathrm{G} 191 \mathrm{v}}$ was still able to grow in the macrophage-like cell line J774A.1, albeit initially at a slower rate than the parental strain. Therefore, the LPS $\mathrm{O}$ antigen does not appear to be required for survival inside macrophages, although early intracellular growth was impaired. The susceptibility to normal serum, but resistance to intracellular killing, of $\mathrm{WbtI}_{\mathrm{G} 191 \mathrm{v}}$ was similar to that of a non-encapsulated mutant of LVS described by Sandström et al. (1988). However, the genetic and biochemical nature of that mutant was not determined. One concern was that mutant $\mathrm{WbtI}_{\mathrm{G} 191 \mathrm{~V}}$ was an LPS phase variant that converted to a $F$. novicida-like LPS (Cowley et al., 1996). However, the LPS O antigen from this mutant did not react with antiserum to $F$. novicida or to the parent strain. Another concern was that mutant $\mathrm{WbtI}_{\mathrm{G} 191 \mathrm{~V}}$ was a 'grey' colony variant, which has also been reported to lack $\mathrm{O}$ antigen (Hartley et al., 2005). There were many phenotypic similarities between the LVS greycolony variant and $\mathrm{WbtI}_{\mathrm{G} 191 \mathrm{v}}$. However, sequence analysis of the wbtI gene of a grey-colony variant that we isolated showed no base change or deletion from that of the parental strain or published LVS genome sequence. Therefore, it appears that any complete loss of $\mathrm{O}$ antigen may result in the 'grey' phenotype, which as mentioned above, may in part be due to the presence of IS sequences isftu2 and isftu1 upstream and downstream of the Oantigen locus.

Mutant $\mathrm{WbtI}_{\mathrm{G} 191 \mathrm{~V}}$ was more resistant to killing by sodium deoxycholate than the parental strain, which contrasted with results obtained by Cowley et al. (2000), who found that most $\mathrm{O}$-antigen-defective mutants were more susceptible to killing by deoxycholate than the parental strain. However, the mutants tested by Cowley et al. (2000), were derived from $F$. novicida, which contains an $\mathrm{O}$ antigen distinct from that of the LVS. The ability of Gram-negative bacteria to exclude hydrophobic detergents such as deoxycholate depends largely upon the LPS maintaining the stability of the outer membrane through interaction with outer-membrane proteins, and maintaining divalent cations and a hydrophilic cell surface (Cowley et al., 2000). However, the LPS O antigen of type A and B strains is composed entirely of dideoxyglycoses, and contains the sugar 4,6-dideoxy-4-formamido-D-glucose, which is not present in F. novicida (Vinogradov et al., 2004). Furthermore, it was determined that a large amount of the LPS from type A and B strains was extracted into the phenol phase following hot aqueous phenol extraction (unpublished data). Therefore, it is probable that the unusual LPS glycosyl composition of type A and B strains makes the bacterial surface hydrophobic, resulting in enhanced interaction with detergents such as sodium deoxycholate and reduced binding of Congo red.

An important feature of mutant $\mathrm{WbtI}_{\mathrm{G} 191 \mathrm{~V}}$ is that it was highly attenuated in mice following IN challenge, again indicating that the $\mathrm{O}$ antigen is required for virulence. The IN route was used to evaluate the capability of each strain to disseminate from the lungs to other tissues, and hence is a better measure of invasiveness than the IP route. Even within 2 days post IN challenge there were more than 2 logs fewer cells of the bacterial mutant present in the tissues than the parental strain, whereas the parental strain and complemented mutant $\mathrm{WbtI}_{\mathrm{G} 191 \mathrm{~V}}:$ :pFNLTP/wbtI continued to multiply in the tissues until the death of the animal. In contrast, the mutant strain continued to diminish in numbers until at sometime after 4 days post-challenge it was completely cleared from all tissues. Since the mutant was not quickly cleared from the tissues, it would be expected that a protective immune response would develop. Although $\mathrm{WbtI}_{\mathrm{G} 191 \mathrm{~V}}$ did induce protection against a relatively low IP challenge dose with the parental strain $\left(25 \times \mathrm{LD}_{50}\right)$, less protection was provided against a higher challenge dose $\left(75-250 \times \mathrm{LD}_{50}\right)$. However, increasing the immunization dose did increase the resistance to higher challenge doses. The IP route was used for challenge because although not natural, it is the most invasive route and therefore a more sensitive indicator of adaptive immunity, as this route bypasses many aspects of innate immunity. Nonetheless, these results indicate that a complete $\mathrm{O}$ antigen does contribute to maximum induction of a protective immune response. Since the LVS strain itself provides only route-dependent protection against challenge with type A F. tularensis (Chen et al., 2003; 
Conlan et al., 2005; Shen et al., 2004), mice immunized with $\mathrm{WbtI}_{\mathrm{G} 191 \mathrm{~V}}$ were not challenged with a type A strain, but similar studies with a type A mutant are in progress.

\section{ACKNOWLEDGEMENTS}

This work was supported by grant U54-AI57168 from NIAID/NIH to the mid-Atlantic Regional Center for Excellence, by grant DAMD1703-1-0008 from the US Army Medical Research and Material Command, and in part by the Department of Energy-funded (DEFG09-93ER-20097) Center for Plant and Microbial Complex Carbohydrates. We thank Dr May Chu, Centers for Disease Control, for supplying F. tularensis subsp. holarctica strain LVS, Dr Karen Elkins, US Food and Drug Administration, for providing $F$. novicida strain U112 and advice on macrophage phagocytosis of $F$ tularensis, Anna Champion and Gretchen Berg for technical assistance, Jane Duncan for advice, and the animal care staff at the Center for Molecular Medicine and Infectious Diseases for assistance with handling and monitoring animals. We gratefully acknowledge Tina Guina, Mitchell Brittnacher and Rajinder Kaul at the University of Washington for sharing with us the DNA sequence of the $F$. novicida strain U112 O-antigen gene cluster. We also thank Anders Sjöstedt, Umeå University, for kindly providing vector pPV, Daphne Rainey for bioinformatics advice, and Alan Cross for review of the manuscript.

\section{REFERENCES}

Ahmed, F. \& Inzana, T. J. (2004). Subtractive Hybridization: a Tool to Identify Potential Virulence Factors in Francisella tularensis, p. 64. Second Annual Mid-Atlantic Microbial Pathogenesis Meeting, Wintergreen, VA.

Baron, G. S. \& Nano, F. E. (1998). MglA and MglB are required for the intramacrophage growth of Francisella novicida. Mol Microbiol 29, 247-259.

Bates, P. A. \& Sternberg, M. J. (1999). Model building by comparison at CASP3: using expert knowledge and computer automation. Proteins (Suppl. 3), 47-54

Bernier, S. P. \& Sokol, P. A. (2005). Use of suppression-subtractive hybridization to identify genes in the Burkholderia cepacia complex that are unique to Burkholderia cenocepacia. J Bacteriol 187 5278-5291.

Chen, W., Shen, H., Webb, A., Kuolee, R. \& Conlan, J. W. (2003). Tularemia in BALB/c and C57BL/6 mice vaccinated with Francisella tularensis LVS and challenged intradermally, or by aerosol with virulent isolates of the pathogen: protection varies depending on pathogen virulence, route of exposure, and host genetic background. Vaccine 21, 3690-3700.

Chen, W., Kuolee, R., Shen, H., Busa, M. \& Conlan, J. W. (2005). Tolllike receptor 4 (TLR4) plays a relatively minor role in murine defense against primary intradermal infection with Francisella tularensis LVS. Immunol Lett 97, 151-154.

Ciucanu, I. \& Kerek, F. (1984). A simple and rapid method for the permethylation of carbohydrates. Carbohydr Res 131, 209-217.

Cole, L. E., Elkins, K. L., Michalek, S. M., Qureshi, N., Eaton, L. J., Rallabhandi, P., Cuesta, N. \& Vogel, S. N. (2006). Immunologic consequences of Francisella tularensis live vaccine strain infection: role of the innate immune response in infection and immunity. J Immunol $176,6888-6899$.

Conlan, J. W., Chen, W., Shen, H., Webb, A. \& KuoLee, R. (2003). Experimental tularemia in mice challenged by aerosol or intradermally with virulent strains of Francisella tularensis: bacteriologic and histopathologic studies. Microb Pathog 34, 239-248.

Conlan, J. W., Shen, H., Kuolee, R., Zhao, X. \& Chen, W. (2005). Aerosol-, but not intradermal-immunization with the live vaccine strain of Francisella tularensis protects mice against subsequent aerosol challenge with a highly virulent type A strain of the pathogen by an $\alpha \beta \mathrm{T}$ cell- and interferon gamma-dependent mechanism. Vaccine 23, 2477-2485.

Cowley, S. C. \& Elkins, K. L. (2003). Multiple T cell subsets control Francisella tularensis LVS intracellular growth without stimulation through macrophage interferon $\gamma$ receptors. $J$ Exp Med 198, 379-389.

Cowley, S. C., Myltseva, S. V. \& Nano, F. E. (1996). Phase variation in Francisella tularensis affecting intracellular growth, lipopolysaccharide antigenicity and nitric oxide production. Mol Microbiol 20, 867-874.

Cowley, S. C., Gray, C. J. \& Nano, F. E. (2000). Isolation and characterization of Francisella novicida mutants defective in lipopolysaccharide biosynthesis. FEMS Microbiol Lett 182, 63-67.

Darling, R. G., Catlett, C. L., Huebner, K. D. \& Jarrett, D. G. (2002). Threats in bioterrorism. I: CDC category A agents. Emerg Med Clin North Am 20, 273-309.

Dennis, D. T., Inglesby, T. V., Henderson, D. A., Bartlett, J. G., Ascher, M. S., Eitzen, E., Fine, A. D., Friedlander, A. M., Hauer, J. \& other authors (2001). Tularemia as a biological weapon: medical and public health management. JAMA ( $\mathrm{A}$ Am Med Assoc) 285, 2763-2773.

DeShazer, D., Waag, D. M., Fritz, D. L. \& Woods, D. E. (2001) Identification of a Burkholderia mallei polysaccharide gene cluster by subtractive hybridization and demonstration that the encoded capsule is an essential virulence determinant. Microb Pathog 30, 253-269.

Ellis, J., Oyston, P. C., Green, M. \& Titball, R. W. (2002). Tularemia. Clin Microbiol Rev 15, 631-646.

Fortier, A. H., Slayter, M. V., Ziemba, R., Meltzer, M. S. \& Nacy, C. A. (1991). Live vaccine strain of Francisella tularensis: infection and immunity in mice. Infect Immun 59, 2922-2928.

Golovliov, I., Sjostedt, A., Mokrievich, A. \& Pavlov, V. (2003). A method for allelic replacement in Francisella tularensis. FEMS Microbiol Lett 222, 273-280.

Hajjar, A. M., Harvey, M. D., Shaffer, S. A., Goodlett, D. R., Sjöstedt, A., Edebro, H., Forsman, M., Byström, M., Pelletier, M. \& other authors (2006). Lack of in vitro and in vivo recognition of Francisella tularensis subspecies lipopolysaccharide by Toll-like receptors. Infect Immun 74, 6730-6738.

Harakava, R. \& Gabriel, D. W. (2003). Genetic differences between two strains of Xylella fastidiosa revealed by suppression subtractive hybridization. Appl Environ Microbiol 69, 1315-1319.

Hartley, G., Taylor, R., Prior, J., Newstead, S., Hitchen, P. G., Morris, H. R., Dell, A. \& Titball, R. W. (2005). Grey variants of the live vaccine strain of Francisella tularensis lack lipopolysaccharide $\mathrm{O}$-antigen, show reduced ability to survive in macrophages and do not induce protective immunity in mice. Vaccine 24, 989-996.

Hopla, C. F. \& Hopla, A. K. (1994). Tularemia. In Handbook of Zoonoses, pp. 113-126. Edited by G. W. Beran \& J. H. Steele. Boca Raton, FL: CRC Press.

Inzana, T. J. (1983). Electrophoretic heterogeneity and interstrain variation of the lipopolysaccharide of Haemophilus influenzae. J Infect Dis 148, 492-499.

Inzana, T. J. \& Anderson, P. (1985). Serum factor-dependent resistance of Haemophilus influenzae type $\mathrm{b}$ to antibody to lipopolysaccharide. J Infect Dis 151, 869-877.

Inzana, T. J., Glindemann, G. E., Snider, G., Gardner, S., Crofton, L., Byrne, B. \& Harper, J. (2004). Characterization of a wild-type strain of 
Francisella tularensis isolated from a cat. J Vet Diagn Invest 16, 374-381.

Joiner, K. A. (1988). Complement evasion by bacteria and parasites. Annu Rev Microbiol 42, 201-230.

Larsson, P., Oyston, P. C., Chain, P., Chu, M. C., Duffield, M., Fuxelius, H. H., Garcia, E., Hälltorp, G., Johansson, D. \& other authors (2005). The complete genome sequence of Francisella tularensis, the causative agent of tularemia. Nat Genet 37, 153-159.

Li, J. \& Rosen, B. P. (1998). Steric limitations in the interaction of the ATP binding domains of the ArsA ATPase. J Biol Chem 273, 6796-6800.

Li, J. W., Inoue, Y., Miyazaki, M., Pu, H., Kondo, A. \& Namba, M. (2000). Growth inhibitory effects of ATP and its derivatives on human fibroblasts immortalized with ${ }^{60} \mathrm{Co}$-gamma rays. Int $\mathrm{J} \mathrm{Mol}$ Med 5, 59-62.

Li, J., Waters, S. B., Drobna, Z., Devesa, V., Styblo, M. \& Thomas, D. J. (2005). Arsenic ( +3 oxidation state) methyltransferase and the inorganic arsenic methylation phenotype. Toxicol Appl Pharmacol 204, 164-169.

Liu, L., Spilker, T., Coenye, T. \& LiPuma, J. J. (2003). Identification by subtractive hybridization of a novel insertion element specific for two widespread Burkholderia cepacia genomovar III strains. J Clin Microbiol 41, 2471-2476.

Maier, T. M., Havig, A., Casey, M., Nano, F. E., Frank, D. W. \& Zahrt, T. C. (2004). Construction and characterization of a highly efficient Francisella shuttle plasmid. Appl Environ Microbiol 70, 7511-7519.

Merkle, R. K. \& Poppe, I. (1994). Carbohydrate composition analysis of glycoconjugates by gas-liquid chromatography/mass spectrometry. Methods Enzymol 230, 1-15.

Newton, H. J., Sansom, F. M., Bennett-Wood, V. \& Hartland, E. L. (2006). Identification of Legionella pneumophila-specific genes by genomic subtractive hybridization with Legionella micdadei and identification of $\operatorname{lp} n E$, a gene required for efficient host cell entry. Infect Immun 74, 1683-1691.

Parsons, Y. N., Banasko, R., Detsika, M. G., Duangsonk, K., Rainbow, L., Hart, C. A. \& Winstanley, C. (2003). Suppression-subtractive hybridisation reveals variations in gene distribution amongst the Burkholderia cepacia complex, including the presence in some strains of a genomic island containing putative polysaccharide production genes. Arch Microbiol 179, 214-223.

Penn, R. L. (2005). Francisella tularensis (tularemia). In Mandell, Douglas, and Bennett's Principles and Practice of Infectious Diseases, pp. 2674-2685. Edited by G. L. Mandell, J. E. Bennett \& R. Dolin. Philadelphia, PA: Elsevier Churchill Livingstone.

Phillips, N. J., Schilling, B., McLendon, M. K., Apicella, M. A. \& Gibson, B. W. (2004). Novel modification of lipid A of Francisella tularensis. Infect Immun 72, 5340-5348.

Prior, J. L., Prior, R. G., Hitchen, P. G., Diaper, H., Griffin, K. F., Morris, H. R., Dell, A. \& Titball, R. W. (2003). Characterization of the O antigen gene cluster and structural analysis of the $\mathrm{O}$ antigen of Francisella tularensis subsp. tularensis. J Med Microbiol 52, 845-851.

Sambrook, J., Fritsch, E. F. \& Maniatis, T. (1989). Molecular Cloning: a Laboratory Manual, 2nd edn. Cold Spring Harbor, NY: Cold Spring Harbor Laboratory.

Sandström, G., Löfgren, S. \& Tärnvik, A. (1988). A capsule-deficient mutant of Francisella tularensis LVS exhibits enhanced sensitivity to killing but diminished sensitivity to killing by polymorphonuclear leukocytes. Infect Immun 56, 1194-1202.
Sayle, R. A. \& Milner-White, E. J. (1995). RASMOL: biomolecular graphics for all. Trends Biochem Sci 20, 374.

Shen, H., Chen, W. \& Conlan, J. W. (2004). Susceptibility of various mouse strains to systemically- or aerosol-initiated tularemia by virulent type A Francisella tularensis before and after immunization with the attenuated live vaccine strain of the pathogen. Vaccine 22, 2116-2121.

Sjöstedt, A. (2005). Family III. Francisellaceae, fam. nov. In Bergey's Manual of Systematic Bacteriology, 2nd edn, pp. 199-210. Edited by G. Garrity, D. J. Brenner, N. R. Kreig, J. T. Staley, D. R. Boone, P. De Vos, M. Goodfellow, F. A. Rainey, G. M. Garrity \& K.-H. Schleiffer. New York: Springer.

Staples, J. E., Kubota, K. A., Chalcraft, L. G., Mead, P. S. \& Petersen, J. M. (2006). Epidemiologic and molecular analysis of human tularemia, United States, 1964-2004. Emerg Infect Dis 12, 1113-1118.

Sturiale, L., Garozzo, D., Silipo, A., Lanzetta, R., Parrilli, M. \& Molinaro, A. (2005). New conditions for matrix-assisted laser desorption/ionization mass spectrometry of native bacterial R-type lipopolysaccharides. Rapid Commun Mass Spectrom 19, 1829-1834.

Thompson, J. D., Higgins, D. G. \& Gibson, T. J. (1994). CLUSTAL W: improving the sensitivity of progressive multiple sequence alignment through sequence weighting, position-specific gap penalties and weight matrix choice. Nucleic Acids Res 22, 4673-4680.

Timoney, J. F., Gillespie, J. H., Scott, F. W. \& Barlough, J. E. (1988). The genus Francisella. In Hagan and Bruner's Microbiology and Infectious Diseases of Domestic Animals, pp. 132-135. Edited by J. F. Timoney, J. H. Gillespie, F. W. Scott \& J. E. Barlough. Ithaca, NY: Cornell University Press.

Titball, R. W. \& Sjöstedt, A. (2002). Francisella tularensis: an overview. ASM News 69, 558-563.

Vinogradov, E. V., Shashkov, A. S., Knirel, Y. A., Kochetkov, N. K., Tochtamysheva, N. V., Averin, S. F., Goncharova, O. V. \& Khlebnikov, V. S. (1991). Structure of the O-antigen of Francisella tularensis strain 15. Carbohydr Res 214, 289-297.

Vinogradov, E. V., Bock, K., Holst, O. \& Brade, H. (1995). The structure of the lipid A-core region of the lipopolysaccharides from Vibrio cholerae O1 smooth strain 569B (Inaba) and rough mutant strain 95R (Ogawa). Eur J Biochem 233, 152-158.

Vinogradov, E., Perry, M. B. \& Conlan, J. W. (2002). Structural analysis of Francisella tularensis lipopolysaccharide. Eur J Biochem 269, 6112-6118.

Vinogradov, E., Conlan, W. J., Gunn, J. S. \& Perry, M. B. (2004). Characterization of the lipopolysaccharide O-antigen of Francisella novicida (U112). Carbohydr Res 339, 649-654.

Ward, C. K., Lawrence, M. L., Veit, H. P. \& Inzana, T. J. (1998). Cloning and mutagenesis of a serotype-specific DNA region involved in encapsulation and virulence of Actinobacillus pleuropneumoniae serotype 5a: concomitant expression of serotype $5 \mathrm{a}$ and 1 capsular polysaccharides in recombinant A. pleuropneumoniae serotype 1 . Infect Immun 66, 3326-3336.

Winstanley, C. (2002). Spot the difference: applications of subtractive hybridisation to the study of bacterial pathogens. J Med Microbiol 51, 459-467.

York, W. S., Darvill, A. G., McNeil, M., Stevenson, T. T. \& Albersheim, P. (1985). Isolation and characterization of plant cell walls and cell-wall components. Methods Enzymol 118, 3-40.

Edited by: N. High 